This is the version of the chapter accepted for publication in Cine-Ethiopia: The History and Politics of Film in the Horn of Africa published by Michigan University Press DOI: 10.14321/j.ctv1fxmf1

Accepted version downloaded from SOAS Research Online: $\underline{\text { http://eprints.soas.ac.uk/32029 }}$

\title{
Cine-ETHiopia
}

\section{THE HISTORY AND POLITICS OF FILM IN THE HORN OF AFRICA}

\author{
Edited by
}

Michael W. Thomas, Alessandro Jedlowski \& Aboneh Ashagrie 


\section{Table of contents}

\section{INTRODUCTION}

Introducing the Context and Specificities of Film History in the Horn of Africa, Alessandro Jedlowski, Michael W. Thomas \& Aboneh Ashagrie

\section{CHAPTER 1}

From Ph,en3 ß巿(Yeseytan Bet - “Devil's House”) to 7D: Mapping Cinema's Multidimensional Manifestations in Ethiopia from its Inception to Contemporary Developments, Michael W. Thomas

\section{CHAPTER 2}

Fascist Imperial Cinema: An Account of Imaginary Places, Giuseppe Fidotta

\section{CHAPTER 3}

The Revolution has been Televised: Fact, Fiction and Spectacle in the 1970s and 80s, Kate Cowcher

\section{CHAPTER 4}

"The dead speaking to the living": Religio-cultural Symbolisms in the Amharic Films of Haile Gerima, Tekletsadik Belachew

\section{CHAPTER 5}

Whether to Laugh or to Cry? Explorations of Genre in Amharic Fiction Feature Films, Michael W. Thomas 
CHAPTER 6

Women's Participation in Ethiopian Cinema, Eyerusalem Kassahun

\section{CHAPTER 7}

The New Frontiers of Ethiopian Television Industry: TV Serials and Sitcoms, Bitania Taddesse

\section{CHAPTER 8}

Migration in Ethiopian Films, at Home and Abroad, Alessandro Jedlowski

\section{CHAPTER 9}

A Wide People with a Small Screen: Oromo Cinema at Home and in Diaspora, Teferi Nigussie Tafa and Steven W. Thomas

\section{CHAPTER 10}

Eritrean Films between Forced Migration and Desire of Elsewhere, Osvaldo Costantini and Aurora Massa

\section{CHAPTER 11}

Somali Cinema: A Brief History between Italian Colonization, Diaspora and the New Idea of Nation, Daniele Comberiati

\section{INTERVIEWS}

Debebe Eshetu (actor and director), interviewed by Aboneh Ashagrie

Behailu Wassie (scriptwriter and director), interviewed by Michael W. Thomas

Yidnekachew Shumete Desalegn (director and producer), Interviewed by Alessandro Jedlowski 


\title{
INTRODUCTION
}

\section{Introducing the Context and Specificities of Film History in the Horn of Africa}

\author{
Alessandro Jedlowski, Michael W. Thomas \& Aboneh Ashagrie
}

This collection of essays constitutes the first systematic attempt at describing and analysing the history and current developments of film production and circulation in Ethiopia. As such, it is a necessary and overdue attempt at filling a significant gap in the scholarship about cinema in Africa. It is indeed striking to note that, despite the dynamism of the Ethiopian film sector during the twentieth century, in most if not all the key reference books on African cinema published in English over the past three decades Ethiopia is almost absent (Barlet 2000; Diawara 1992 and 2010; Ukadike 1994; Harrow 2007 and 2013; Tcheuyap 2011).

The exception that confirms the rule is the abundant number of essays which analyse the work of the Ethiopian born director Haile Gerima (Cham 1982; Pfaff 2004; G. Thomas 2013; M.W. Thomas 2014), whose experience as a filmmaker, however, took off while he was a student in the United States, and remains until today profoundly connected to the North American independent film production environment (but see Tekletsadik Belachew's essay in this book for an analysis of the traces of specifically Amharic and Orthodox Christian elements in his work). Similarly, some scholarly attention has been devoted to the work of other notable Ethiopian filmmakers who produced the core of their work in the Unites States, such as Yemane Demissie (Cham 1998; Leclerq 2002) and Salem Mekuria (Petty 1999; Woubshet 2010).

While the importance and quality of these authors' work is undisputable, it is equally true that this analysis alone cannot make us understand the complexity, historical depth, and aesthetic and narrative specificities of the cinema production which has emerged in the region throughout the past 
century. As a number of recent publications have highlighted (Ashagrie 2013; Barlet 2015; Tadesse 2016; Jedlowski 2015; M.W. Thomas 2015), over the past two decades Ethiopia has experienced a boom in video film production which has attracted much international interest. In order to fully understand the long-term dynamics that influenced it and rightly contextualize its specificities, however, a larger, overarching perspective is needed. If, then, the core of the present book analyses the past fifteen years of digital film production, a substantial effort is put into highlighting, through a few introductive chapters, key moments of Ethiopian film history, from the early film screenings under the rule of Emperor Menelik II to the impact of Fascist policies and representations during the Italian occupation, from the first Ethiopian celluloid productions at the crepuscule of Haile Selassie's government to the articulated film policies enforced under the authoritarian administration of the Derg regime - moments which have received little scholarly attention but whose analysis can help us gain a much better understanding of film production and circulation in Ethiopia.

Furthermore, as we will better discuss below, while putting together this book we understood that a focus limited to the production happening in what constitutes today's Ethiopia would limit our understanding of what is taking place in a region, the Horn of Africa, in which frontiers have been porous and movable for centuries, and where cultural productions circulate well beyond the boundaries of today's nation-states. If then, the key focus of the book is the analysis of films produced in Ethiopia and by Ethiopian nationals in the diaspora, chapters ten and eleven discuss also Eritrean and Somali films. These productions circulate also in Ethiopia, and the analysis of the history of cinema in these two countries, while significantly different from the Ethiopian one, can provide a number of important insights to better understand the current developments taking place in the whole region, including Ethiopia.

\section{The missing link with the "African cinema" scholarship}


The history of Ethiopia and of the Horn of Africa more generally presents a number of specificities that had fundamental impacts in shaping filmmaking practices in the region. These specificities are explored in detail in the first chapter of this collection and there is no point in rehearsing them here (see also chapter nine, ten and eleven of this collection). However, it is important to underline that the peculiar historical itinerary of Ethiopia as a country had an important role in making Ethiopian cinema distinctly different from other cinematic traditions which emerged around the continent, somehow also contributing to its marginalization. Three aspects come to mind as the most relevant: the linguistic insularity of Ethiopian cultural production; the web of international connections derived from the peculiar trajectory of Ethiopian history; and Ethiopia's specific experience of colonialism and nationalism. We will briefly discuss the first two points here, and then develop the third more extensively in next section of this introduction.

As David Turton has underlined, discussing Will Kymlicka’s work,

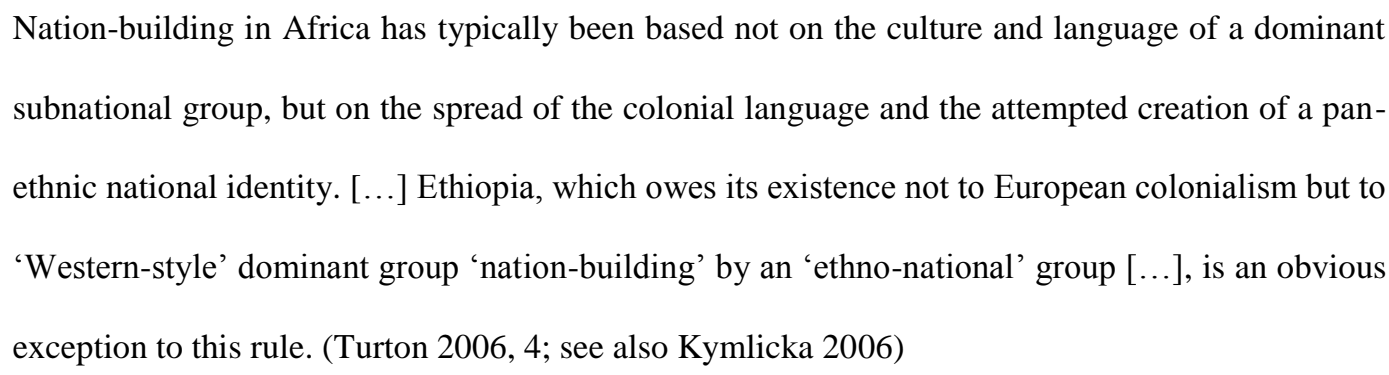

The consequences of this exceptionality are numerous and affected the historical trajectory of Ethiopia as a nation in multiple ways. We will focus more closely on the internal consequences of this historical specificity in the next section of this introduction, when analyzing the applicability of the concept of national cinema to Ethiopian film production. What is important to underline here is the impact that this trajectory has had on Ethiopia's integration into the larger world of African cultural production. Despite colonialism's violence and brutality throughout sub-Saharan Africa it has been a powerful accelerator of globalization processes (Geschiere, Meyer and Pels 2008), and colonial languages have played an important role in this dynamic, creating a bridge among the political, intellectual and artistic elites of different countries, be them Francophone, Anglophone or 
Lusophone. Furthermore, colonial powers invested in the creation of a number of media infrastructures which, in some countries, provided the basis for the development of local film production after independence (Diawara 1992). France's administration in particular, after the end of colonial rule invested significant political and economic resources into supporting the emergence of Francophone African cinema helping it to gain better pan-African and international exposure. These strategies were obviously aimed at maintaining a strong hold on the intellectual elite of the newly independent African countries (Hoefert de Turégano 2005), but they equally had an important role in making the cinema production emerging from these regions of Africa more visible internationally than that of other African regions.

In Ethiopia the adoption of Amharic as national language (including the use of the Amharic script) had a series of important consequences for the development of Ethiopian cinema as well as for its international recognition. Bitania Tadesse (2016) suggests that the fact that Ethiopian films were made in Amharic limited their circulation if compared to films produced in other Francophone or Anglophone countries, but this is only partly true if we consider that most of the best known African films produced in the 1970s and 1980s by filmmakers such as Ousmane Sembene, Djibril Diop Mambety, Ola Balogun or Idrissa Ouedraogo were in African languages. What, in our opinion, ended up being more influential is the fact that local intellectual production, including the studies and press coverage about emerging visual culture practices in Ethiopia, was produced strictly in Amharic and thus remained inaccessible to most scholars of African cinema, who tended to adopt comparative approaches and could hardly speak any of the languages of the regions they were working on (apart from, in the case of African scholars, that of their native ethnic group).

If Ethiopia remained somehow excluded from colonialism-driven processes of modernization and globalization, its different ruling elites pursued long-term efforts to achieve state-driven modernization (Tibebu 1995; Donham 1999). This also implied that, while looking for alternative models, Ethiopia entered very early into non-Eurocentric global networks which eventually 
connected it to non-Western countries such as Japan (Clarke 2011), Mexico (Savarino 2004), Cuba (Valdés 1979), and Russia (Korn 1986; Patman 1993). As for many other African countries, the interaction with Russia was undoubtedly the one that had most consequences on the development of cinema and television in Ethiopia (see Kate Cowcher's chapter in this book; see also Woll 2004), and Russia remained implicitly an important reference for young filmmakers until today, as the editors of this book have experienced how the Pushkin Centre (the Russian Cultural Centre in Addis Ababa, one of the oldest foreign cultural centres on the African continent) plays host to the weekly meets of the association of young Ethiopian filmmakers (Alatinos). If these transversal, nonEurocentric connections make Ethiopia a particularly interesting case study for understanding the development of non-Western models of modernity, they can equally be seen as one of the causes for the marginalization of Ethiopian cultural production (and cinema in what interests us more closely). In fact, combined with the linguistic isolation discussed above, they participated in making Ethiopian cinema less visible to mainstream scholars based in Western universities or working in western languages.

\section{Ethiopian history, cinema and the nation}

One of the key specificities of Ethiopian history if compared to other African countries is Ethiopia's experience of colonialism, characterized by the short and extremely violent Italian occupation (1936-1941) under the Fascist regime of Benito Mussolini (Ben-Ghiat and Fuller 2016). Despite the deep economic, social, political and cultural consequences of the occupation, thanks to its long-term resistance to the Italian invasion and its steady reunification after World War II, Ethiopia remains the symbol of an idealized free and independent Africa, particularly among the members of the African American and Caribbean diasporas. International discourses about the country, as well as early visual representations were significantly influenced by these idealizations and by essentialized understandings of Ethiopian history connected to them (Moses 1998; Scott 1993 and 2004). The 
idea of a land, Ethiopia, with a millenary Christian tradition and free from the yoke of western colonialism also influenced the way Ethiopia was represented in the large number of western documentary films produced in the early twentieth century (see Haars et al. 2014). The legacy of these visual archives, together with the later repertoire of images of war and famine that emerged from the 1970s, is still strongly felt, and constitutes the ground for recurring stereotypical representations of Ethiopia in the international media. Until today, the omnipresence of such contradicting images as eternal monuments of the Imperial past and its splendour, celebrations of African warriors who fought against western colonialism, and images of war-torn regions and starving children in need of humanitarian aid, have participated in masking the vibrant, independent visual culture that emerged within the country, making it almost invisible to international audiences, even within Africa itself.

At the same time, the complex historical trajectory of the Ethiopian nation did not have an impact only on the international representation of the country - it also contributed in fragmenting the internal discourse about the country's past. In Alessandro Triulzi's words, Ethiopia is a country "overburdened" by its past $(2002,280)$, in which the writing of history has become one of the major battle fields among the different ethnic groups that compose the nation. While some are prone to emphasizing the resistance to colonialism and highlighting the glorious past of the Ethiopian Empire, others point to the same processes to denounce key moments of territorial and political affirmation of one ethnic group over the others.

One should not be surprised therefore if the very name Ethiopia has come to signify different things to different people. For Teshale, Ethiopia is 'the second oldest Christian polity in Africa [...]'. To opponents of the Ethiopian state, the country is said to have increasingly identified with its basic feudal 'Abyssinian nature'. Hence the name Ethiopia is rejected by Oromo nationalist historians today as the embodiment of a foreign 'colonial' imposition which subverted the canons of Oromo civilization and cut short its national history. (Triulzi 2002, 284; quoting Tibebu 1995; Ibbsa 1990; and Jalata 1993) 
Conflicting visions of the past inevitably ground contrasting projections into the future, creating political tensions which are reflected by the trajectories of film production and circulation both within the country and throughout the diaspora (see chapter eight, nine, ten and eleven). These tensions pose a major challenge to the project this book itself wants to pursue: how to speak about an "Ethiopian cinema" when there is so much disagreement about what "Ethiopia" as a nation is or is supposed to be?

The concept of national cinema is a disputed one (Hjort and Mackenzie 2000; Williams 2002). Much of the existing scholarship takes Benedict Anderson's analysis of nations as "imagined communities" (1982) as a starting point to discuss the way in which cinema participates in shaping discourses about national identity. But after closer scrutiny, Anderson's notion seems insufficient to analyse the complexity of the social and cultural processes involved in the formation of national cinema canons and discourses. As Rick Altman argues "Anderson concentrates on the moment when a nation was formed and stops there, failing to acknowledge the ongoing nature of the process he has described" (Altman 1998, quoted in Williams 2002, 3). As the Ethiopian case shows extremely well, nation building is a fluid, conflicting, and never-ending process. Nationhood is thus "not merely established, it must be maintained; its definition, therefore, will inevitably shift over time" (Williams 2002, 3). By adopting a historical approach, this book then highlights, through the diversity of the case studies explored in each of the chapters, the complex negotiations and changing conceptions of nationhood, identity and belonging that have appeared on Ethiopian screens over the years.

As Andrew Higson highlighted in a seminal essay on the concept of national cinema,

There are perhaps two central methods, conceptually, of establishing or identifying the imaginary coherence, the specificity, of a national cinema. First, there is the method of comparing and contrasting one cinema to another, thereby establishing varying degrees of otherness. Second, there is what might be termed a more inward-looking process, exploring the cinema of a nation in 
relation to other already existing economies and cultures of that nation state. $(1989,38$; emphasis added)

As we proceeded in assembling this book, the second of the options suggested by Higson became more and more relevant for us, as the discussions we had with the different contributors were helping us in better understanding the inherent complexity of what constitutes "the national" within Ethiopia. Following Higson again, it became evident that

\footnotetext{
In considering cinema in terms of cultural identity, it is necessary also to pay attention to the processes by which cultural hegemony is achieved within each nation-state; to examine the internal relations of diversification and unification, and the power to institute one particular aspect of a pluralistic cultural formation as politically dominant and to standardise or naturalise it. Historical accounts of national cinemas have too often been premised on unproblematised notions of nationhood and its production. The search for a stable and coherent national identity can only be successful at the expense of repressing internal differences, tensions and contradictions differences of class, race, gender, region, etc.. $(1989,44)$
}

The overall structure of this book is informed by these preoccupations and thus adopts an approach to the study of Ethiopian cinema which focuses not only on the films produced in Ethiopia, but also, on the variety of films that circulate within the country and its diaspora - films that are able to "speak" the diversity of languages spoken in the country, and address the different ethnic constituencies that compose the Ethiopian mosaic, despite and beyond the central (hegemonic) role of the Amharic language in the history of the country. This approach is reflected in the structure of the book, as well as in its title, which points at the geographic spaces of Ethiopia and the Horn of Africa (within which the films discussed in the book are produced and/or circulated) rather than at the disputable definition of what would constitute an "Ethiopian" cinema, to go beyond any essentialist understanding of "Ethiopianness" that the definition of a national cinema could implicitly convey. 


\section{Chapter outlines}

After the first three chapters provide valuable historical scope, the following four chapters discuss the most well-known and established experiences of cinema emerging from Ethiopia (films made in Amharic). The final four chapters then reflect Ethiopia's cultural porosity and transnational reaches, discussing films made in languages spoken in Ethiopia and the Horn of Africa (Oromo, Tigrinya and Somali) as well as diaspora filmmakers making films in European languages. In order to further augment this scholarship, the chapters are followed by three interviews, with actor and director Debebe Eshetu, scriptwriter and director Behailu Wassie, and filmmaker and producer Yidnekachew Shumete Desalegn, offering first-hand accounts of cinema's past and present in Ethiopia.

We open the conversation with Michael W. Thomas's chapter acting as a comprehensive historical introduction to the study of cinema in Ethiopia, weaving together the history of cinema exhibition with that of film production and consumption, over the past century. This work maps the complexities of cinema in Ethiopia, tracing its changing nature and relationship with the country and its peoples. Acting as a guide to important historical sources and bringing together the small but important publications in the field allows the piece to be our springboard into the greater expanse of Ethiopian film and screen studies.

Shedding more light on film in Ethiopia during the Italian occupation from 1936-1941, the second chapter by Giuseppe Fidotta explores the role films and Italian film producers played in the fascist attempt at colonizing the Horn of Africa. Italian fascist cinema is then considered with regards to its political and ideological espousals and in turn how Italian films projected Ethiopia and the other Italian occupied territories as experimental places where fantasies of fascist power and identity were played out.

In the following chapter, Kate Cowcher focuses on the critical role film and the moving image played in the rise and fall of the military Derg regime. Harnessing a vivid narrative to explore this 
era in Ethiopian history, Cowcher intertwines the turmoil of the revolution and analyses of various documentary and feature films to highlight their crucial impacts on events. Grounding the chapter in film history and theory draws our attention to the often neglected role screens, both big and small, play in the mediating and unfolding of revolution.

After Cowcher makes reference to how the Derg-era film policy failed to commandeer Haile Gerima's Harvest: 3000 Years and cinema of liberation, Tekletsadik Belachew gives us a detailed analysis of Haile Gerima's Amharic films. With a particular focus on the religious and culturally specific symbolisms, often overlooked by film scholars and commentators outside of Ethiopia, Tekletsadik's analysis moves from a broader biography of Haile Gerima to close readings of films such as Harvest: 3000 Years (1976), Adwa: An African Victory (1999), and Teza (2008). Tracing much of the aesthetic roots of these films to Amharic oral traditions, the analysis nuances the longstanding characterization of film festival films made by Africans (and members of the diaspora) as harnessing the narratives, structures and styles of oral folklore with a particular emphasis on songs and their structural and symbolic meanings.

With Tekletsadik's chapter acting as a transition into the contemporary era, we refocus the lens to look at the emergent commercially oriented film industry based in Addis Ababa. Michael W. Thomas charts the commercialization of these locally produced Amharic films through a frame of contextually grounded genre criticism, discussing the significance of theatrical releases, melodrama and the prevalence of the Amharic term fiker/love in the naming of local genres. This chapter reconstitutes genre criticism into a tool for observing localized generic regimes, their evolution and relationships with each other and local/foreign sources which leads to explorations of how the form and style of this commercial cinema is underpinned by a specific Ethiopian "melodramatic imagination."

Eyerusalem Kassahun and Bitania Tadesse respectively harness first-hand interviews with local film and TV practitioners to underpin research centered on the less charted areas of female 
participation in cinema in Ethiopia and the impacts of the recent successes in Amharic TV series and sitcoms. Eyerusalem, herself a filmmaker, considers the important role women have played and currently maintain in relation to cinema in Ethiopia. This chapter offers a cross-section of the film industry by harnessing personal interviews with actresses, directors, producers and distributors along with an analysis of female representation in films directed by women filmmakers.

Bitania's research draws our attention to the significance of the smaller screen as her chapter chronicles the rise of television dramas and comedies in Ethiopia. As practitioners of cinema and other cultural productions often crossover in Ethiopia this chapter helps broaden the parameters of our book to help better appreciate the diverse spectrum of performance arts and audio-visual media and their intertwined relationships in Ethiopia. With particular attention afforded to issues emanating from the relationship between producers of television content and the TV stations, the chapter maps the differences between the production and distribution models of the state-run broadcaster and its competitors based abroad.

The four chapters which come after are all concerned with decentralizing the Amharic-centered narrative which the volume has traced in its central part. Alessandro Jedlowski constructs a comparison between the local Amharic film industry in Ethiopia and emerging diaspora filmmakers scattered across the globe. Analyzing the recent trend in making films on the theme of migration, Jedlowski compares the contexts of production and reception of the films of Italian based Dagmawi Yimer and Tewodros Teshome, a major film producer, distributor and cinema-owner in Ethiopia. The framing of migration and diaspora filmmakers by Jedlowski gives rise to the remaining chapters which trace the experiences of films made in other languages spoken in Ethiopia and the Horn of Africa region.

Oromo films, their position within diaspora communities, and their conscious attempts at reviving Oromo traditions through narrative device are discussed by Teferi Nigussie Tafa and Steven W. Thomas. The essay analyzes the recent emergence of Oromo cinema in a transnational 
context and examines both the historical conditions that Oromo filmmakers had to overcome both within Ethiopia and in diaspora in order to produce their work, and the specific formal qualities of Oromo cinema as an experimental art that places their ethnic traditions into conversation with a rapidly changing world.

This investigation into discovering an Oromo-centered film style is then juxtaposed by the ethnographic research which has informed the chapter by Aurora Massa and Osvaldo Constantini discussing two films made by members of the Eritrean diaspora in Ethiopia and America respectively. The migratory experience, political challenges and global desires are all key themes which inflect on the filmmakers and their films, raising the issue of the role films play in the construction of imaginaries and narratives which impact on experiences of migration as much as political, economic and historical causes.

Drawing together the historic and diasporic narrative strands and once again broadening the reach of this volume, the final chapter by Daniele Comberiati discusses the impacts of Italian colonialization and recent efforts by members of the Somali diaspora on Somali filmmaking. The chapter explores how Somali cinema from the 1950s until contemporary times has contributed to a re-thinking of the colonial past and the independence era. In particular, with reference to colonial and postcolonial films, the chapter sheds light on how the brief but intense Italian Trusteeship Administration of Somalia (1949-1960) changed the flow of Somali cinema history and its lingering effects today. In its final part, the chapter also analyzes the emerging phenomenon of film production in the Somali diaspora and the Somali-language film industry (dubbed "Somaliwood," and based in Ohio), to understand and pose questions relating to the film industry's role in forming the idea of a "new" Somali nation.

The book then concludes with three interviews with influential figures in the film industry in Ethiopia. With these, we return to the source of the study, offering interesting first-hand accounts of 
the contemporary moment cinema in Ethiopia finds itself in, filled with useful information and insights for future studies.

Note: Whenever Ethiopian authors' works that have been published in English are cited, their names are referred to the way that they are printed in source materials, with their last name coming first in the reference list. This rule is also applied to filmmakers who live and/or are well known in the West. The two most prevalent examples of these in this volume are referring to Gabriel (for Teshome Habte Gabriel) and Gerima (for Haile Gerima). Whenever other Ethiopian names are cited they appear in the native standard, with the first name being the name a person is known by and referred to (the second name being that of their father and the third name that of their grandfather etc.). The Romanization of Amharic/Ethiopic script and names has been standardized to limit the use of accents readers of English are otherwise unaccustomed to. Finally, all quotations from Amharic, Oromiffa, Tigrinya, Somali or Italian sources have been translated (unless otherwise stated) by the respective chapters' author(s). 


\section{Bibliography}

Altman, Rick. 1998. Film/Genre. London: British Film Institute.

Anderson, Benedict. 1982. Imagined Communities: Reflections on the Origin and Spread of Nationalism. London: Verso Books.

Ashagrie, Aboneh. 2013. "African Cinema: The 6th Ethiopian International Film Festival, 7 - 14 November 2011." Matatu, Journal for African Culture and Society 41: 453-464.

Barlet, Olivier. 2000. African Cinemas: Decolonizing the Gaze. London: Zed Books.

Barlet, Olivier. 2015. "Ethiopian cinema today: An interview with Ethiopian filmmakers Yamrot Nigussie, Hiwot Admasu Getaneh, Hermon Hailay, Adanech Admasu, and Debebe Daniel Negatu." Black Camera 6 (2): 221-228.

Ben-Ghiat, Ruth, and Mia Fuller, eds. 2016. Italian colonialism. New York: Palgrave MacMillan.

Cham, Mbye B. 1982. "Artistic and ideological convergence: Ousmane Sembene and Haile Gerima." Ufahamu: A Journal of African Studies 11 (2): 140-152.

Cham, Mbye B. 1998. “African cinema in the nineties.” African Studies Quarterly 2 (1): 47-51.

Clarke, Joseph Calvitt. 2011. Alliance of the Colored Peoples: Ethiopia and Japan Before World War II. Oxford: James Currey.

Diawara, Manthia. 2010. African Film: New Forms of Aesthetics and Politics. Munich: Prestel.

Diawara, Manthia. 1992. African Cinema: Politics and Culture. Bloomington: Indiana University Press.

Donham, Donald Lewis. 1999. Marxist Modern: An Ethnographic History of the Ethiopian Revolution. Berkeley: University of California Press.

Geschiere, Peter; Birgit Meyer, and Peter Pels. 2008. Readings in Modernity in Africa. Oxford: James Currey. 
Harrow, Kenneth W. 2013. Trash: African Cinema from Below. Bloomington: Indiana University Press.

Harrow, Kenneth W. 2007. Postcolonial African Cinema: From Political Engagement to Postmodernism. Bloomington: Indiana University Press.

Haars, Martin; Giovanna Trento, Thomas Zitelmann, Hugues Fontaine, Didier Morin and Itsushi Kawase. 2014. "Film: Ethiopia and Eritrea in Film." In Encyclopaedia Aethiopica Y-Z, Vol. 5. Edited by S. Uhlig. Wiesbaden: Otto Harrassowitz Verlag.

Higson, Andrew. 1989. “The concept of national cinema.” Screen 30 (4): 36-46.

Hjort, Mette, and Scott Mackenzie, eds. 2000. Cinema and Nation. London: Routledge.

Hoefert de Turégano, Teresa. 2005. "Sub-Saharan African cinemas: The French connection." Modern \& Contemporary France 13 (1): 71-83.

Ibbsa, Sisay. 1990. "The place of Gada in independent Oromia.” Wadhaansso 2: 3-8.

Jalata, Asafa. 1993. Oromia and Ethiopia: State Formation and Ethnonational conflict, 18681992. London: Lynne Rienner.

Jedlowski, Alessandro. 2015 "Screening Ethiopia: A preliminary study of Ethiopian film production's history and contemporary developments." Journal of African Cinemas 7 (2): 169-185.

Korn, David A. 1986. Ethiopia, The United States and The Soviet Union. Carbondale: Southern Illinois University Press.

Kymlichka, Willa A. 2006. "Emerging western models of multination federalism: Are they relevant for Africa." In Ethnic Federalism: The Ethiopian Experience in Comparative Perspective, edited by David Turton, 32-64. Oxford: James Currey.

Leclercq, Emmanuel. 2002. “Afrique 1990-2002: Etat des lieux du cinéma militant.” Les Temps Modernes 4: 526-544.

Moses, Wilson Jeremiah. 1998. Afrotopia: The Roots of African American Popular History. Cambridge: Cambridge University Press. 
Patman, Robert G. 1993. "Soviet-Ethiopian relations: The horn of dilemma." In Troubled Friendships: Moscow's Third World Ventures, edited by Margot Light, 110-139. London: British Academic Press.

Petty, Sheila. 1999. "The archaeology of origin: Transnational visions of Africa in a borderless cinema." African Studies Review 42 (02): 73-86.

Pfaff, Françoise. 2004. "Haile Gerima: From Africa to the Americas: Interviews with Haile Gerima." In Focus on African Films, edited by Françoise Pfaff, 203-220. Bloomington: Indiana University Press.

Savarino, Franco. 2004. "La actuación de México en una crisis internacional: el caso de Etiopía (1935-1937)." Iberoamericana (2001-) 16: 17-33.

Scott, William R. 2004. "The Ethiopian ethos in African American thought." International Journal of Ethiopian Studies 1 (2): 40-57.

Scott, William R. 1993. The Sons of Sheba's Race: African-Americans and the Italo-Ethiopian War, 1935-1941. Bloomington: Indiana University Press.

Tadesse, Bitania. 2016. "Revolutionary Ethiopia through the lens of the contemporary film industry." Northeast African Studies 16 (1): 167-196.

Tcheuyap, Alexie. 2011. Postnationalist African Cinemas. Manchester: Manchester University Press.

Thomas, Greg. 2013. “Close-Up: On Teza, cinema, and American empire: An Interview with Haile Gerima.” Black Camera 4 (2): 84-104.

Thomas, Michael W. 2015. "The local film sensation in Ethiopia: Aesthetic comparisons with African cinema and alternative experiences.” Black Camera 7 (1): 17-41.

Thomas, Michael W. 2014. "Harvest 3000 Years/Mirt Sost Shi Amat (Haile Gerima, 1976)." In Africa's Lost Classics: New Histories of African Cinema, edited by Lizelle Bisschoff and David Murphy, 182-189. London: Legenda. 
Tibebu, Teshale. 1995. The Making of Modern Ethiopia (1896-1974). Lawrenceville: Red Sea Press.

Triulzi, Alessandro. 2002. "Battling with the past: New frameworks for Ethiopian historiography." In Remapping Ethiopia: Socialism and After, edited by Wendy James et al. 276288. Oxford: James Currey.

Turton, David, ed. 2006. Ethnic Federalism: The Ethiopian Experience in Comparative Perspective. Oxford: James Currey.

Ukadike, Nwachukwu Frank. 1994. Black African Cinema. Berkley: University of California Press.

Valdés, Nelson P. 1979. "Cuba y la guerra entre Somalia y Etiopía." Estudios de Asia y Africa 14.2 (40): 244-267.

Williams, Alan Larson, ed. 2002. Film and Nationalism. London: Rutgers University Press.

Woll, Josephine. 2004. "The Russian connection: Soviet cinema and the cinema of Francophone Africa." In Focus on African Films, edited by François Pfaff, 233-40. Bloomington: Indiana University Press.

Woubshet, Dagmawi. 2010. “An interview with Salem Mekuria.” Callaloo 33 (1): 314-317. 